\title{
ЕКСПЕРИМЕНТАЛЬНІ ПРАКТИЧНІ ЗАНЯТТЯ 3 МЕТОДИКИ НАВЧАННЯ МАЙБУТНІХ СЛОВЕСНИКІВ ШКІЛЬНОГО АНАЛІЗУ ЕПІЧНИХ ТВОРІВ
}

\section{Гричаник Н. I.}

\section{ВСТУП}

Підготовка майбутніх учителів зарубіжної літератури до шкільного аналізу творів світового письменства є комплексною проблемою, від успішного розв'язання якої залежить вирішення низки важливих питань соціального, культурологічного та педагогічного змісту. Практика засвідчує, що значна частина майбутніх учителів літератури не володіє на належному рівні методикою аналізу художнього твору. А це, як правило, у майбутньому позначається на їхній педагогічній діяльності: на уроках зарубіжної літератури шкільний аналіз почасти підмінюють переказом твору загалом або окремих його частин, інколи опрацюванням відомих критичних матеріалів, вибірковим читанням певних епізодів. Причиною цього $є$ насамперед неналежна фахова підготовка майбутнього вчителя, невміння продуктивно використовувати літературознавчі знання в практичній діяльності під час проведення шкільного аналізу художнього твору.

Ще одним суттєвим недоліком шкільного вивчення творів зарубіжної літератури $є$ те, що вчителі-словесники приділяють недостатньо уваги художній специфіці програмового твору, залишаючи поза увагою його родово-жанрові особливості, порушуючи нерозривну єдність змісту і форми як засадничих літературознавчих категорій, що акумулюють уявлення про внутрішню суть і зовнішню форму твору, дають змогу всебічно пізнати художнє явище. Це стосується й одного із родів літератури - епосу, адже вивчення епічних творів як явища словесного мистецтва відіграє винятково важливу роль у літературній освіті учнів. Готовність учнів до аналізу епічних творів безпосередньо залежить від особистісного підходу до виучуваного матеріалу, від сприйняття епічного твору залежно від життєвого досвіду вихованця, його загального розвитку, інтелектуального рівня, читацьких інтересів, уміння самостійно мислити й формулювати правильні висновки та узагальнення. Відтак зростають вимоги до вчителя-словесника: до його здатності враховувати вікові та індивідуальні особливості учнів, уміння продуктивно реалізовувати всі етапи вивчення епічного твору, 
ефективно використовувати традиційні й інноваційні шляхи його аналізу, методи, прийоми, форми і види навчальної діяльності, розкривати учням духовні пошуки письменника, відображені в образах і ситуаціях епічного твору, спонукати їх до самостійного осмислення зображених автором проблем людського життя, проникати в глибинну сутність твору. Означене вище дає підстави стверджувати, що правильно організований і проведений шкільний аналіз епічних творів буде максимально сприяти активній пізнавальній роботі учнів на уроці, глибокому засвоєнню тексту, оволодінню різними способами читання, що істотно впливатиме на якість їхньої літературної освіти, розвиток інтелектуальної сфери і піднесення культури читання.

Виходячи з вищезазначеного, можемо зробити висновок, що виняткової ваги набуває проблема навчання студентів-філологів шкільного аналізу епічних творів під час аудиторного навчання (на лекціях і лабораторно-практичних заняттях) та в позааудиторний час (виконання ними завдань самостійної роботи). Детально зупинимося на характеристиці експериментальних практичних занять 3 методики викладання зарубіжної літератури, під час проведення яких було застосовано методи, прийоми, види і форми роботи, що сприяли формуванню в майбутніх словесників відповідних методичних умінь.

\section{1. Роль і місце експериментальних практичних занять із методики навчання студентів-філологів шкільного аналізу епічних творів}

Під експериментальним практичним заняттям 3 методики викладання зарубіжної літератури розуміємо відповідну форму навчального заняття, під час реалізації якої відбувається послідовний аналіз важливих теоретичних питань, їх практичне засвоєння шляхом виконання попередньо сформульованих різнорівневих завдань i поступове формування професійно-методичних умінь та навичок.

Експериментальні практичні заняття характеризувалися такими ознаками:

1. Науковий, дослідницько-експериментальний, творчий підходи.

2. Спрямованість на поглиблення, розширення, деталізацію, закріплення набутих теоретичних знань.

3. Логічна послідовність, структурованість і вмотивованість різного роду завдань і педагогічних ситуацій.

4. Орієнтація на вироблення і відпрацювання відповідних професійно-методичних умінь та навичок у майбутніх фахівців ${ }^{1}$.

\footnotetext{
${ }^{1}$ Мачинська Н І., Стельмах С.С. Сучасні форми організації навчального процесу у вищій школі : навчально-методичний посібник. Львів : Львівський державний університет внутрішніх справ, 2012. 180 с.
} 
Мета означених практичних занять - 3 урахуванням грунтовних напрацювань літературознавчої та методичної наук, знань, отриманих під час експериментальних лекцій, та первинних вмінь і навичок, набутих під час проведення експериментальних лабораторних робіт, формувати в студентів методичні вміння та навички проведення шкільного аналізу різножанрових епічних творів.

Основні завдання:

1. Формування навичок і вмінь організації, проведення шкільного аналізу художнього твору відповідно до його родово-жанрової специфіки, обсягу, складності матеріалу, вікових особливостей учнів.

2. Оволодіння навичками проведення шкільного аналізу епічних творів різних жанрів у старших класах закладів загальної середньої освіти.

3. Накопичення професійно необхідного досвіду роботи 3 текстом епічного твору ${ }^{2}$.

Практичні заняття було проведено в три етапи (підготовчий, основний, етап аналізу), кожен з яких, відповідно, мав свою мету і основні завдання. Оскільки під час проведення експериментальних практичних занять були активно задіяні майбутні вчителі-словесники, то, відповідно, й завдання були орієнтовані на викладача-методиста і студентів.

Таблиця 1

Етапи проведення експериментальних практичних занять

\begin{tabular}{|c|c|c|c|}
\hline & Підготовчий етап & Основний етап & Етап аналізу \\
\hline Мета & $\begin{array}{l}\text { Попередня } \\
\text { підготовка до } \\
\text { проведення } \\
\text { практичного заняття. }\end{array}$ & $\begin{array}{l}\text { Реалізація основних } \\
\text { навчальних завдань } \\
\text { щодо навчання } \\
\text { студентів проводити } \\
\text { шкільний аналіз } \\
\text { епічних творів. }\end{array}$ & $\begin{array}{l}\text { Визначення } \\
\text { досягнень, недоліків } \\
\text { або помилок у роботі } \\
\text { викладача та } \\
\text { діяльності студентів } \\
3 \text { метою їх усунення. }\end{array}$ \\
\hline $\begin{array}{c}\text { Завдання } \\
\text { i практичні } \\
\text { діï } \\
\text { викладача }\end{array}$ & \begin{tabular}{|l} 
- звернення до \\
робочої навчальної \\
програми з метою \\
осмислення теми і \\
визначення мети; \\
- окреслення \\
завдань заняття; \\
- складання плану \\
практичної роботи з \\
методичними \\
вказівками;
\end{tabular} & \begin{tabular}{|l} 
- оголошення теми, \\
мети, завдань \\
заняття, його \\
логічного зв'язку з \\
іншими формами \\
навчальних занять; \\
- перевірка рівня \\
теоретичної та \\
практичної \\
готовності студентів \\
до заняття
\end{tabular} & $\begin{array}{l}\text { - аналіз усіх етапів } \\
\text { проведеного заняття, } \\
\text { діяльності } \\
\text { викладача, участі } \\
\text { студентів; } \\
\text { - визначення } \\
\text { позитивних сторін та } \\
\text { недоліків } \\
\text { проведеного заняття; } \\
\text { - іх методична } \\
\text { корекція. }\end{array}$ \\
\hline
\end{tabular}

${ }^{2}$ Мачинська Н.I., Стельмах С.С. Сучасні форми організації навчального процесу у вищій школі : навчально-методичний посібник. Львів : Львівський державний університет внутрішніх справ, 2012. 180 с. 
Продовження таблиці 1

\begin{tabular}{|c|c|c|c|}
\hline & Підготовчий етап & Основний етап & Етап аналізу \\
\hline $\begin{array}{c}\text { Завдання } \\
\text { і практичні } \\
\text { дї } \\
\text { викладача }\end{array}$ & $\begin{array}{l}\text { - добір та } \\
\text { рекомендація } \\
\text { основної та } \\
\text { додаткової } \\
\text { літератури з теми } \\
\text { для попереднього } \\
\text { опрацювання } \\
\text { студентами; } \\
\text { - проведення } \\
\text { попередніх } \\
\text { консультацій; } \\
\text { - уявне } \\
\text { моделювання } \\
\text { заняття, розподіл } \\
\text { часу на огляд } \\
\text { кожного питання, } \\
\text { добір відповідних } \\
\text { методів, прийомів і } \\
\text { видів навчальної } \\
\text { діяльності; } \\
\text { - розроблення } \\
\text { різнорівневих } \\
\text { завдань, } \\
\text { контрольних } \\
\text { запитань; } \\
\text { - добір наочного і } \\
\text { дидактичного } \\
\text { матеріалу для } \\
\text { самостійної роботи } \\
\text { студентів. }\end{array}$ & $\begin{array}{l}\text { 3 використанням } \\
\text { відповідних методів і } \\
\text { прийомів; } \\
\text { - постановка } \\
\text { запитань, } \\
\text { спрямованих на } \\
\text { розкриття, } \\
\text { деталізацію різних } \\
\text { аспектів одного } \\
\text { питання; } \\
\text { - перевірка й аналіз } \\
\text { планів-конспектів } \\
\text { або фрагментів } \\
\text { уроків, розроблених } \\
\text { студентами; } \\
\text { - керівництво } \\
\text { процесом } \\
\text { обговорення } \\
\text { студентами } \\
\text { переглянутого } \\
\text { фрагменту уроку, } \\
\text { коригування їхньої } \\
\text { роботи; } \\
\text { - перевірка } \\
\text { виконаних } \\
\text { студентами } \\
\text { випереджальних } \\
\text { завдань; } \\
\text { - контроль за } \\
\text { самостійною } \\
\text { роботою студентів; } \\
\text { - керівництво } \\
\text { роботою студентів, } \\
\text { сприяння } \\
\text { формуванню в них } \\
\text { методичних умінь і } \\
\text { навичок; } \\
\text { - оцінювання } \\
\text { роботи студентів на } \\
\text { занятті. }\end{array}$ & \\
\hline
\end{tabular}


Закінчення таблиці 1

\begin{tabular}{|c|c|c|c|}
\hline & Підготовчий етап & Основний етап & Етап аналізу \\
\hline $\begin{array}{c}\text { Завдання } \\
\text { і практичні } \\
\text { дї̈ } \\
\text { студентів }\end{array}$ & $\begin{array}{l}\text { - опрацювання } \\
\text { лекційного матеріалу } \\
\text { з визначеної } \\
\text { проблеми; - } \\
\text { вивчення та аналіз } \\
\text { рекомендованої } \\
\text { літератури, } \\
\text { створення опорних } \\
\text { конспектів за } \\
\text { теоретичним } \\
\text { матеріалом; } \\
\text { - письмове } \\
\text { виконання } \\
\text { практичних завдань; } \\
\text { - надання допомоги } \\
\text { викладачеві. }\end{array}$ & $\begin{array}{l}\text { - участь в } \\
\text { обговоренні } \\
\text { теоретичних питань, } \\
\text { висловлювання та } \\
\text { відстоювання } \\
\text { власної думки; } \\
\text { - демонстрування } \\
\text { виконаних } \\
\text { випереджальних } \\
\text { завдань та їх } \\
\text { обговорення; } \\
\text { - репрезентація } \\
\text { розробленого плану- } \\
\text { конспекту уроку або } \\
\text { його фрагменту; } \\
\text { - програвання } \\
\text { власної розробки; } \\
\text { - творча співпраця } 3 \\
\text { викладачем- } \\
\text { методистом. }\end{array}$ & 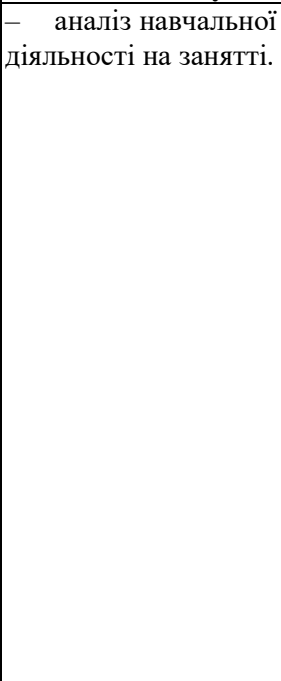 \\
\hline
\end{tabular}

Із метою визначення результативності проведених занять, ураховуючи комунікативно-діяльнісний i проблемний підходи до вивчення курсу методики викладання зарубіжної літератури, формування умінь та навичок проведення шкільного аналізу епічних творів було визначено такі види експериментальних практичних занять:

1. Репродуктивно-проектувальні практичні заняття. Такий вид практичного заняття передбачав репродуктивне відтворення теоретичного матеріалу. Студенти виконували елементарні завдання, які сприяли формуванню таких умінь і навичок:

1) правильне i вільне володіння теоретико-літературними поняттями;

2) спроможність забезпечити всебічний аналіз досліджуваного питання;

3) здатність виокремлювати методичну проблему та обговорювати ії;

4) встановлення певних фактів або зв'язків за допомогою літературознавчого або методичного матеріалу;

5) виконання нескладних проектувальних завдань.

2. Конструктивно-проектувальні практичні заняття. Означений вид передбачав взаємозв'язок іiі із практичною діяльністю. Він сприяв вияву індивідуальних рис особистості шляхом виконання заздалегідь сформульованих завдань. Така форма навчальної діяльності сприяла формуванню вмінь та навичок: 
1) знаходження підтвердження теоретичних знань у практиці сучасної школи;

2) здатність дискутувати, обговорювати, доводити певну думку;

3) поява пізнавальної мотивації та професійної зацікавленості;

4) оволодіння вміннями створювати педагогічний продукт наближено до шкільних реалій, утілювати його, адаптувати до сучасних вимог роботи з текстом художнього твору.

3. Дослідно-проектувальні практичні заняття передбачали активне залучення майбутніх словесників до проектувальної творчості, виконання складних дослідницько-пошукових завдань. У результаті проведення таких занять у студентів були сформовані вміння і навички:

1) нестандартного розв'язання практичних завдань;

2) здатність до тісної педагогічної співпраці 3 викладачем, готовність до професійного діалогу;

3) вивчення і дослідження певного методичного явища з метою його наукового обгрунтування;

4) моделювання деталізованих планів-конспектів уроків, створення педагогічної атмосфери в навчальній аудиторії, входження в роль учителя літератури;

5) практична реалізація поетапності дослідження художнього твору в закладі загальної середньої освіти.

\section{2. Практичне впровадження експериментальних практичних занять в освітній процес студентів-філологів}

Різновид конструктивно-проектувального практичного заняття було використано під час висвітлення теми «Основні етапи вивчення епічного твору». На підготовчому етапі його проведення студенти ознайомилися 3 планом заняття, опрацювали рекомендовану викладачем навчальну літературу, створили міні-конспект основних теоретичних питань, займалися виконанням випереджальних практичних завдань.

Мета:

- навчальна: показати теоретичну співвіднесеність матеріалу лекції та його наочного втілення; практично репрезентувати основні етапи вивчення епічного твору і показати їх взаємозв'язок; розкрити особливості його сприйняття; визначити домінантні прийоми читацької діяльності; продемонструвати наочно методику аналізу різножанрових епічних творів;

- розвивальна: розвивати вміння самостійного й творчого проектування навчальних ситуацій, добору необхідної інформації та іiі творчої інтерпретації; готовність до творчого використання набутків передового досвіду провідних учителів зарубіжної літератури; 
- виховна: усвідомлення важливості роботи 3 текстом художнього твору.

Вид заняття: конструктивно-проектувальне практичне заняття.

\section{План}

I. Теоретичний блок

1. Специифіка підготовки до сприйняття епічного твору як один із етапів його вивчення.

2. Етап читання художнього твору.

3. Підготовка до аналізу художнього твору. Основні прийоми і види навчальної діяльності на изьому етапі.

4. Шкільний аналіз - основний етап вивчення епічних творів. Особливості його проведення в умовах загальноосвітнього навчального закладу.

5. Підсумковий етап вивчення художнього твору.

II. Практичний блок

Виконання студентами практичних завдань з теми заняття.

На початку заняття викладач наголосив на актуальності та важливості теми практичного заняття в курсі методики викладання зарубіжної літератури, окреслив мету, завдання заняття, уточнив специфіку роботи, визначив регламент часу на проведення або виконання окремих видів робіт. Організаційна діяльність викладача активізувала увагу студентів, дисциплінувала їx, націлила на продуктивну діяльність у рамках обмеженого в часі навчального простору.

Із метою простеження основних етапів роботи над змістом твору в умовах навчальної аудиторії спільно зі студентами було обрано епічний твір, що став предметом вивчення на практичному занятті, - новела Ф. Кафки «Перевтілення». Відповідно до чинної програми її вивчають в 11 класі закладах загальної середньої освіти.

На занятті почергово було закцентовано увагу на всіх основних етапах вивчення епічного твору. Спочатку студентам було запропоновано опрацювати пам'ятку успішного проведення етапу підготовки до сприйняття епічного твору, спираючись на яку вони виконували творчо-пошукові завдання.

Пам'ятка «Як успішно провести етап підготовки до сприйняття епічного твору"

1. Сплануйте, скільки часу можете відвести на підготовку до сприйняття.

2. Ураховуйте спецчифіку виучуваного твору та зміст теоретичного матеріалу про нього.

3. Зважайте на вікові та індивідуальні особливості учнів, їхні читацькі інтереси. 
4. Добирайте иіккавий та маловідомий теоретичний матеріал.

5. Обирайте такі прийоми і форми роботи, які спонукають до виникнення в учнів інтересу прочитати твір.

Завдання 1. Запропонуйте цікаві та результативні методичні прийоми або форми роботи, що їх можна використати на етапі підготовки до сприйняття художнього твору.

На практичному занятті студенти представили підготовлені вдома методичні матеріали, довівши цим необхідність етапу підготовки до сприйняття. Для прикладу проілюструємо виконання цього завдання деякими студентами.

Студентка Н., беручи до уваги орієнтовну тему уроку «Зображення відчуження особистості в новелі «Перевтілення» Ф. Кафки», на етапі підготовки до сприйняття запропонувала розповідь про пам'ятник Ф. Кафці в Празі. Вона продемонструвала ілюстративне зображення пам'ятника і повідомила таку інформацію: у Празі багато місиь нагадує про Ф. Кафку. Особливу увагу перехожсих привертає химерний пам'ятник письменнику, що з'явився в Празі 2003 року. За задумом автора - чеського скульптора Ярослава Рони, йому важливо було передати художній світ Кафки, який не піддається логічному тлумаченню. Тому ц̆ пам'ятник - величезний порожній костюм чоловіка, а на ньому - фігура самого генія Кафки.

Далі студентка 3 метою простеження співвідношення між поданим матеріалом і складною біографією Ф. Кафки рекомендувала провести евристичну бесіду, запропонувавши такі запитання до неї:

1. Як ви вважаєте, чому скульптор Ярослав Рон створив саме такий пам'ятник письменнику-модерністу?

2. 3 якою метою він зобразив величезний порожній костюм? Що, на вашу думку, він символізує?

3. Чому фігура Ф. Кафки знаходиться зверху на костюмі?

Підсумовуючи, студентка наголосила на тому, що за життя Франц Кафка був дуже дивакуватим. Він майже ні з ким не спілкувався, жив усамітнено, мав постійний конфлікт із батьком. Займаючись літературною діяльністю, не прагнув оприлюднювати написані твори, склав заповіт, у якому заборонив друкувати твори навіть після його смерті. Оточенню було важко пояснити таку поведінку і спосіб життя письменника. Тому й у літературі він став прозаїком-самітником, художній світ якого не піддається логічному поясненню, теж $€$ дивакуватим, абсурдним, позбавленим логіки. Такими ж є і його герої, зокрема Грегор Замза, образ якого в новелі набуває автобіографічних рис.

Отже, обравши зазначені методичні прийоми і види робіт, студентка успішно підготувала учнів до сприйняття художнього твору. 
Студентка I., визначивши іншу тему уроку - «Ф. Кафка «Перевтілення». Грегор Замза і його родина», спочатку запропонувала скласти асоціативний кущ до слова «щастя». Серед слів, які добирали студенти, найчастіше, траплялися такі: спокій, турбота про інших, упевненість у собі, у своєму майбутньому, бути здоровим, мати люблячу родину, кохати, дихати, прокидатися зранку, бачити наступний день та ін.

Перетин життєвих уявлень студентів з фактами літературного твору вона запропонувала поєднати шляхом створення проблемної ситуації. Студентка дібрала та зачитала складові людського щастя, запропоновані сучасним письменником В. Шевчуком:

1. Наявність живих батьків.

2. Знайти себе в цьому житті.

3. Мати добрий сімейний лад.

4. Не сказати жодного негарного слова.

Потім, використовуючи ці чинники та спираючись на знання студентів фактів із життя Ф. Кафки, студентка передбачила провокативні запитання:

1. Подумайте, яку людину можна назвати щасливою?

2. Чи почував себе щасливим Ф. Кафка? Відповідь обгрунтуйте.

3. Еміль Утіц, товариш письменника по навчанню, згадував, що той «завжди був оточений якоюсь скляною стіною». Як ви гадаєте, чому?

4. Чого, на вашу думку, йому бракувало для повного щастя?

5. Поміркуйте, з якою метою Ф. Кафка, створюючи образ Грегора Замзи, теж показує його невлаштованість у навколишньому світі?

Таким чином, студентка спонукала до продуктивної дискусії, учасники якої стали активними шукачами шляхів і засобів вирішення проблемних ситуацій. Конструктивне спілкування дозволило активізувати пізнавальну діяльність студентів, сприяло розширенню кругозору, формуванню вмінь доцільного поєднання матеріалу про письменника із твором чи його персонажами.

Студентка Ю., звернувшись до теми уроку, присвяченого характеристиці образу Грегора Замзи та його родини, підготовку до сприйняття пропонувала розпочати із читання поезії Ф. Г. Лорки «Повернення з прогулянки».

Убитий небом,

серед форм, які прямують до зміі,

і форм, які відшукують кристал,

я запущу своє волосся.

3 обтятим деревом, що не співає,

і з хлоп'ям, чиє обличчя біле, як яйце. 
Із звірятками, яким розбито голови,

і з водою в лахах сухих стебел.

3 усім, що повила глухоніма утома,

і з метеликом, утопленим в чорнильниці.

Стикаючись із власним обличчям, одмінним щодня.

Убитий небом!

Логічним продовженням підготовки до сприйняття було демонстрування та аналіз репродукції картини Е. Мунка «Крик».

Студентка продумала запитання для аналітичної бесіди:

1. Яке враження на вас справила поезія Ф.Г. Лорки та картина Е. Мунка?

2. Які емоції та настрій передає вірш?

3. Спробуйте витлумачити сенс зображеного на картині. Чому автор зображує агонізуючу від жаху постать людини на тлі кривавочервоного неба?

4. Яким чином можна поєднати зміст поезії та зображене на картині з образом Грегора Замзи?

Підсумком стали іiі слова про те, що неабияке здивування і майже шок (так само, як ліричний герой твору і людина, зображена на картині) відчуває Грегор Замза, який, прокинувшись зранку, побачив, що перетворився на комаху.

Таким чином, студенти усвідомили, що мета етапу підготовки до сприйняття художнього твору - створити відповідну емоційну атмосферу, зацікавити учнів, пробудити в них бажання прочитати твір.

Читання як наступний етап вивчення епічного твору теж відіграє важливу роль у процесі роботи з текстом художнього твору. Обираючи практичні завдання для виконання студентами, спиралися на теорію i технологію розвитку читацької діяльності, розроблену професором О. Ісаєвою. Його головна мета, на думку методиста, - забезпечити повноцінне творче сприйняття художнього твору. При цьому використовували метод творчого читання 3 притаманними йому прийомами.

Студенти отримали випереджальне завдання прочитати новелу Ф. Кафки «Перевтілення» вдома, тому під час практичного заняття їм було запропоновано виконати ряд завдань, які сприяли розвитку в них емоційної вразливості, створенню умов для емпатії, рефлексії, поглибленню вмінь проводити різні види читання, добирати та продумувати відповідні прийоми та види роботи.

3-поміж методичних прийомів творчого читання під час експериментального навчання особливу увагу звертали на прийом повільного читання, який сприяв уважному ставленню до всіх структурних елементів твору, поглибленому вчитуванню в 
літературний текст $з$ метою виокремлення певних домінант. Студентам було запропоновано виконати ряд завдань.

Завдання 2. Уважно, повільно перечитати зміст твору Ф. Кафки «Перевтілення», скласти иитатний план до кожного із розділів новели.

Наведемо приклад цитатного плану твору, що був підготовлений студенткою Р.

1. «Що зі мною сталося?»

2. «Подумати тільки, що за напасть!»

3. «Невже я став тепер менш чутливим?»

4. «Чи був він твариною, якщо музика так хвилювала його?»

5. «Його треба спекатись!»

6. «Гляньте-но, вона здохла! Лежить і не кивається!»

7. «Забудьте нарешті старе!»

Складання цитатного плану сприяло глибшому усвідомленню логіки взаємозв'язків змісту і форми художнього твору.

Акцент було зроблено і на повторному читанні твору з метою його глибокого осмислення і кращого розуміння, поглиблення читацького сприйняття художнього твору. Для цього було практично застосовано прийом «Оживлення картини», що передбачав творчий підхід студентів до переказу кульмінаційного епізоду твору.

Завдання 3. Переказати епізод «бомбардування» яблуками Грегора Замзи батьком, довести його важливість для розкриття ідейного задуму автора.

Під час переказу епізоду студенти звернули увагу на надзвичайну жорстокість батька і абсолютно байдуже ставлення матері до сина. Вони довели, що цей епізод є кульмінаційним у творі, оскільки став доказом трагічного існування Грегора в родині, розкрив авторську ідею - людина у світі самотня, навіть найближчі людини до неї байдужі.

Такий прийом значною мірою посилив увагу до компонентів змісту і форми епічного твору, сприяв удосконаленню зв'язного мовлення, акцентував увагу на ідейно-композиційній ролі персонажа.

Під час експериментального навчання також надавали перевагу прийому коментованого читання, під час якого заглиблювалися в художню канву твору, аналізували основні епізоди, здійснювали спостереження над текстом. Реалізували цей прийом за допомогою таких видів навчальної діяльності: обговорення назви новели та аналіз першої фрази твору. Усі студенти були залучені до обговорення, яке відбувалося у вигляді полемічної бесіди:

1. Поясніть семантику слова «перевтілення». Чому новела Ф. Кафки має таку назву?

2. Твір Ф. Кафки починається фразою: «Одного ранку, прокинувшись від неспокійного сну, Грегор Замза побачив, що він 
обернувся на страхітливу комаху». Як ви гадаєте, чому письменник відразу пояснює суть перетворення?

3. Які паралелі ви можете провести 3 працею Овідія «Метаморфози»?

4. Пригадайте відомі вам із міфології, фольклору та літературних творів перевтілення героїв в іншу істоту. Чим зміна зовнішності Грегора істотно відрізняється від них?

Таким чином, читання як один із етапів вивчення епічного твору відіграє засадничу роль у формуванні методичних умінь майбутніх словесників проводити шкільний аналіз художнього твору. Незнання змісту твору зводить нанівець його аналіз, утрачається відчуття цілісності й довершеності художнього тексту, єдності тріади «текст читач(учень) -учитель».

Етап підготовки до аналізу теж відіграє засадничу роль у процесі організації шкільного аналізу епічних творів. До розгляду тексту твору потрібно братися лише тоді, коли учні, прочитавши твір, збагнули зміст прочитаного. Майбутній учитель повинен з'ясувати рівень сприйняття художнього твору, емоційне враження від нього, труднощі, що виникли під час прочитання тексту, тому їм було запропоновано виконати ряд завдань.

Завдання 4. Звернути увагу на складні слова, що трапляються в тексті. Продумати методику проведення словникової роботи.

Студентам було запропоновано алгоритм-помічник організації та проведення словникової роботи, який став у пригоді в процесі виконання ними завдання.

\section{Алгоритм-помічник}

1. Визначити слова або словосполучення, щ̧о потребують пояснення.

2. Знайти циитатний матеріал, пов'язаний зі словами або словосполученнями.

3. Виписати за тлумачним словником значення слів або словосполучень.

4. Продумати прийоми словникової роботи з метою зацікавлення читачів та усвідомлення ними значення незрозумілих лексем.

5. Визначити слова, які потрібно лише запам'ятати або ж записати до словників чи робочих зошитів.

6. 3'ясувати, чи значення всіх незрозумілих слів або словосполучень пояснено.

7. Підбити підсумки роботи.

Заслуговує на увагу методика словникової роботи, запропонована студенткою Н., яка попередньо визначила ряд складних для розуміння слів, що трапляються в новелі та потребують пояснення. Це слова - 
назви застарілого одягу: ліврея, кашкет, мундир, боа. Використовуючи прийом «Пошук асоціацій», вона звернулася до студентів із запитанням: «Які асоціації у вас виникають із визначеними словами?». Різні варіанти відповідей майбутніх словесників засвідчили зацікавленість організованою роботою, бажання брати активну участь в обговоренні.

Студентка, відходячи від традиційного словникового тлумачення слів, також зробила акцент на використанні наочності. Вона репрезентувала ілюстрації із зображенням одягу.
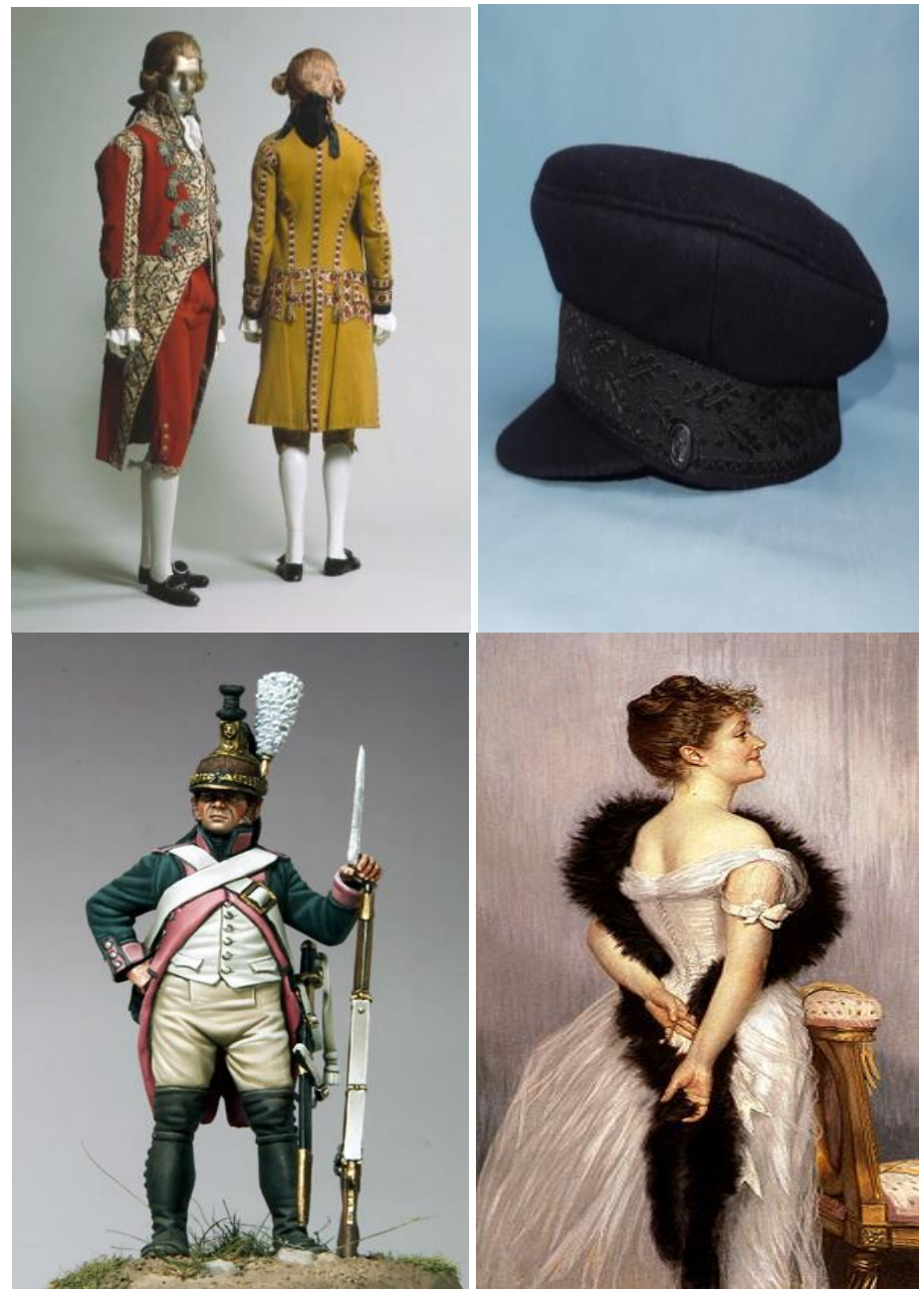
Візуальне сприйняття матеріалу значно активізувало увагу студентів. Вони уважно переглядали ілюстрації, описували побачене i робили спробу пояснити значення слів.

Варіанти їхніх відповідей майже повністю збігалися зі значенням слів, виписаних студенткою з тлумачного словника української мови. Вона зачитала студентам, що

- ліврея - у буржуазних домах і при дворах уніформа особливого крою і певного кольору для лакеїв, швейцарів, кучерів та інших слуг;

- кашкет - чоловічий головний убір з козирком;

- мундир - парадний або буденний одяг певної форми;

- боа - жіночий шарф із хутра або пір'я.

Таким чином, проведена словникова робота стала першим етапом самостійного дослідження художнього тексту.

Створення асоціативного куща - ще один методичний прийом, репрезентований на етапі підготовки до аналізу епічного твору. Викладач наголосив, що мета цього прийому - пов'язувати розрізнені факти, систематизувати інформацію про художній твір, сприяти зміцненню та розширенню творчих здібностей студентів.

Завдання 5. Створити асоиіативний кущ, спираючись на зміст новели Ф. Кафки «Перевтілення».

Усі студенти проявили ініціативність, творчість, креативність, працюючи над розробленням власних асоціативних кущів, представлених на занятті.

Студенти створили асоціативні кущі, пов'язані 3 образом Грегора Замзи.

Наведемо приклад виконаного завдання студенткою I.

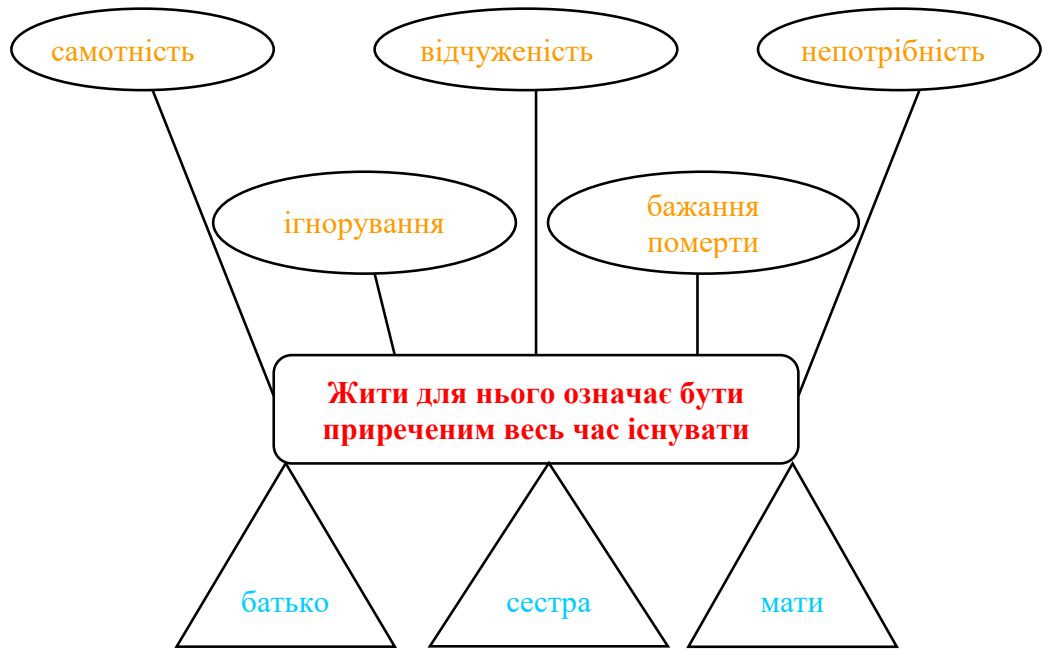


Аналізуючи асоціативні кущі, студенти колективно дійшли висновку про те, що запропонований методичний прийом спонукав їх вільно думати стосовно образу персонажа, стимулював асоціативне мислення, розвивав уміння узагальнювати відомий матеріал.

Проводячи практичне заняття, найбільш детально звернули увагу на eman аналізу епічного твору, оскільки одне 3 основних завдань викладача-методиста - навчити майбутніх словесників аналізувати літературний твір як ідейно-естетичну і змістово-формальну цілісність, доводити відповідність окремих компонентів твору, злагодженість, зумовлену ідейним задумом автора.

До заняття студенти отримали завдання критичного опрацювати, проаналізувати наявні в методичній літературі, рекомендованій викладачем, схеми аналізу епічних творів. Під час експериментального практичного заняття у форматі колективної роботи було складено експериментальну схему аналізу епічного твору.

\section{Експериментальна схема аналізу епічного твору}

1. Назва твору (алегорична, метафорична, символічна, сюжетна, влучна, образна тощо) та ї̈ роль у розкритті ідейного задуму автора.

2. Родово-жанрові особливості твору.

3. Ідейно-тематичний зміст, основна проблематика. Їх актуальнiсть.

4. Художній конфлікт та його роль у творі.

5. Композиційно-сюжетні особливості твору, їх роль у розкритті ідейного задуму твору.

6. Роль позасюжетних елементів (авторських відступів, описів, епіграфів, присвят тощо).

7. Система образів твору, їх поділ на групи. Роль головних персонажів у творі. Ідейне навантаження другорядних персонажів.

8. Мовностильова своєрідність твору.

Під час дослідного навчання на етапі аналізу епічного твору було ефективно використано прийоми евристичного i дослідницького методів: перечитування тексту художнього твору, робота над складанням плану твору і хронології подій у ньому, переказ епізодів, усні відповіді на поставлені запитання, складання опорних тез аналізу епічного твору, самостійний аналіз окремих частин епічного твору, складання повідомлення.

Розповідь відіграє важливу роль у процесі безпосереднього аналізу епічного твору в єдності змісту і форми, тому на занятті було використано методичний прийом «Жанровий коментар», мета якого вчити студентів орієнтуватися в різноманітті жанрового вияву епічних творів, точно їх визначати 3 урахуванням характерних ознак. Застосування цього прийому дало можливість грунтовно розкрити 
жанрову специфіку виучуваного твору. Так, 3'ясовуючи жанрові особливості «Перевтілення», було не просто констатовано його належність до жанру новели, а й пояснено специфіку змістовоформової організації творів таких жанрових різновидів, доведено неочікуваність фіналу твору, оскільки саме такою кінцівкою Ф. Кафка підкреслював трагізм існування людини в сучасному світі.

Усні відповіді на поставлені запитання під час аналізу епічного твору стимулювали до самостійних роздумів про твір, націлювали на результативні пошуки невідомого, допомагали на основі аналізу художнього твору доходити власних висновків щодо змістовоформової специфіки художнього твору.

Запитання для бесіди, запропоновані студентам, стосувалися дотримання принципу взаємозв'язку змісту і форми в процесі аналізу епічного твору:

1. Окресліть ідейно-тематичний зміст новели.

2. Які проблеми порушено у творі? Доведіть їх актуальність для сьогодення.

3. Чому сюжет твору має ознаки фантастики?

4. Виділіть епізоди, пов'язані із зав'язкою твору, ії кульмінацією і розв'язкою.

5. 3 якою метою автор використовує прийом трикратного обрамлення й градаційної епіфори?

Наряду із переказом, перечитуванням окремих епізодів твору, висловлюванням власної думки 3 приводу прочитаного важливим видом роботи стало складання опорних тез аналізу епічного твору.

Завдання 6. Скласти опорні тези до новели Ф. Кафки «Перевтілення» і репрезентувати їх на занятті.

Проілюструємо зразок виконання завдання студенткою Ю., яка склала такі опорні тези вивчення новели.

I. Історія написання новели:

1. Автор розпочав прачювати над створенням оповідання 17 листопада 1912 року, але в повному обсязі завершив його в ніч з 6 на 7 грудня.

2. Разом із творами «Кочегар» $i$ «Вирок» твір мав скласти трилогію під загальною назвою «Сини».

3. У 1914 році автор відсилає оповідання до журналу «Ноей рундшау», але його було відхилено.

4. Уперше було надруковано в жовтні 1915 року в журналі «Вайсе блеттер».

II. Ідейно-тематичний зміст.

Тема: зображення трагічного життя «маленької» людини у ворожому їй світі. 
Ідея: засудження байдужого ставлення рідних людей до головного героя, самотності особистості у світі.

III. Порушені проблеми: взаємостосунки в родині, сенс життя особистості у ворожому світі, життя і смерті, самотності людини, бездуховності людського суспільства, «маленької людини».

IV. Жанр: психологічна новела-міф.

$V$. Композиція твору: зав'язка твору (I частина) - перевтілення Грегора; кульміначія (II частина) - вигнання Грегора батьком, «бомбардування» яблуками; розв'язка (ІІІ частина) - смерть Грегора.

VI. Художній конфлікт: батьки - діти, вороже суспільство особистість.

VII. Образи персонажів: Грегор Замза і його родина (батько, мати $i$ сестра).

У результаті виконання такого завдання було поглиблено вміння студентів аналізувати епічний твір, сприймати художнє явище в єдності змісту й форми; актуалізовано теоретичні знання про складники змісту і форми, зміст оповідання, приведено їх у певну систему. Опорні тези було складено на основі знань з теорії та історії літератури.

Мета підсумкового етапу вивчення епічного твору - перевірити рівень засвоєння реципієнтами літературної теми, розкрити перспективи для майбутнього самостійного осмислення епічного твору та його оцінювання.

Студентам було запропоновано продумати ефективні індивідуальні та групові форми роботи. Вони запропонували виконати завдання на встановлення відповідностей, роботу на картках, розв'язати тести або дати відповіді на запитання літературного диктанту тощо.

\section{ВИСНОВКИ}

Як показало експериментальне навчання, раціонально проведена робота сприяла поглибленню методичних умінь і навичок роботи 3 текстом, усвідомлення мети практичної діяльності - уміння проводити шкільний аналіз літературного твору в школі. Експериментальне впровадження розробленого практичного курсу в навчальний процес вивчення методики викладання зарубіжної літератури 3 метою навчання майбутніх учителів-словесників шкільного аналізу епічних творів дало можливість узагальнити найголовніші науково-теоретичні положення та виробити методичні вміння і навички. Результатом проведених експериментальних форм навчальної діяльності стало значне підвищення рівня методичної підготовки студентів, усвідомлення ними відповідальності педагогічної діяльності, розуміння важливості правильно організованого й ефективно проведеного шкільного аналізу епічних творів. 
Під час експериментального навчання було сформовано такі методичні вміння та навички студентів-філологів щодо проведення шкільного аналізу епічних творів: успішне застосування наукових здобутків літературознавства, історії зарубіжної літератури, методики викладання зарубіжної літератури; уміння виокремлювати істотні відмінності в проведенні шкільного аналізу епічних творів у середній та старшій школах; знання та реалізація всіх етапів вивчення прозового твору; добір та застосування ефективних шляхів аналізу відповідно до жанрової специфіки виучуваного епічного твору; обрання ефективних методів, прийомів і видів роботи 3 текстом епічного твору; виділення та дослідження всіх компонентів змісту і форми, розуміння закономірностей їх взаємодії; моделювання уроків різних типів з вивчення епічного твору та реалізація їх на практиці; виконання завдань пошуково-дослідницького, проблемного характеру; проведення шкільного аналізу епічних творів.

\section{АНОТАЦІЯ}

Подано визначення експериментального практичного заняття. Чітко окреслено його мету і основні завдання, виокремлено домінантні ознаки. Зазначено, що практичні заняття було проведено в три етапи (підготовчий, основний, етап аналізу), кожен із яких, відповідно, мав свою мету і завдання. Під час експериментального навчання було визначено три види експериментальних практичних занять: репродуктивно-проектувальні, конструктивно-проектувальні, досліднопроектувальні, у результаті проведення яких були сформовані конкретні методичні вміння i навички. Наведено приклад конструктивно-проектувального практичного заняття з теми «Основні етапи вивчення епічного твору». Складено план заняття, окреслено триєдину мету. Розглянуто основні етапи вивчення епічного твору на уроках зарубіжної літератури, запропоновано різноманітні методичні прийоми, види і форми робіт, які сприяли формуванню вмінь студентів проводити шкільний аналіз епічних творів.

\section{ЛIТЕРАТУРА}

1. Мачинська Н.I., Стельмах C.C. Сучасні форми організації навчального процесу у вищій школі : навчально-методичний посібник. Львів : Львівський державний університет внутрішніх справ, 2012. 180 с.

Information about the author: Hrychanyk N. I., Assistant at the Ukrainian Language, Literature and Teaching Methods Department Oleksandr Dovzhenko Hlukhiv National Pedagogical University 24, Kiev-Moscow str., Hlukhiv, Ukraine 